Article

\title{
The Case of Hirose Akira: The Ethical Predicament of a Japanese Buddhist Youth during World War II
}

\author{
Kunihiko Terasawa \\ Department of Religion and Philosophy, Wartburg College, Waverly, IA 50677, USA; \\ kunihiko.terasawa@wartburg.edu
}

Received: 24 April 2018; Accepted: 6 June 2018; Published: 10 June 2018

\begin{abstract}
The Japanese Buddhist clergy's collaboration with the Japanese war machine during the Fifteen Year War (1931-1945) is notorious. Yet the struggles of ordinary lay Buddhist youths during World War II remain less publicized. This article examines the case of a young Shinshū Buddhist soldier, Hirose Akira, 廣瀬明 (1919-1947), and scrutinizes the diary he kept between 1939 and 1946. Mobilized between February 1942 and January 1945, Hirose became increasingly disillusioned, especially when he witnessed injustices and the officers' thoughtlessness in ordering junior soldiers to make sacrifices while enjoying their privileges. His diary reveals an early skepticism toward the Japanese embrace of expansionism and the hypocrisy of its justifications for the war of aggression waged against China and Asia as a whole. Independently from the battle's fate, by 1944 Hirose considered that Japan was already defeated because of what he saw as "her own people's ego and selfishness."
\end{abstract}

Keywords: World War II; wartime Japan; warfare; soldiers; violence; Hirose Akira; Shinshū; Pure Land Buddhism; selfishness

\section{Introduction}

Previous research has revealed the extent to which Buddhist leaders and scholars collaborated with Japan's war effort, such as Brian Victoria' Zen at War, Sueki Fumihiko' Kindai Nihon to Bukkyō (Modern Japan and Buddhism), and Nakajima Takeshi' Shinran to Nihonshugi (Shinran and Japanism) etc. ${ }^{1}$ However, Yoshimi Yoshiaki' Grassroots Fascism and Yoshida Yutaka' Nihongunheishi (Japanese military soldiers) analyzed ordinary people's grassroots efforts for the war without investigating religious factors. ${ }^{2}$ This article focuses on the struggles of ordinary lay Buddhist youths during World War II. In particular, we will look at the case of a young Shinshū (True Pure Land) Buddhist soldier, Hirose Akira (1919-1947). Drawing on passages in the diary he kept from 1939 to 1946, I will show how-despite the Shinshū leadership's pro-war stance and the war propaganda-one young man struggled with his faith, denounced military violence, and reached a point where his own understanding of Shinshū and Buddhism as a whole underwent a complete transformation. Hirose's understanding of Shinshū and Buddhism would give an insight to overcome dualism of traditional Shinshū' notion of Shinzoku nitai (ultimate truth and conventional truth; private and public realm) and possibility of constructing a new Buddhist social ethics to resist ultranationaistic ideology and war.

Hirose Akira was the son of a priest from a Shinshū Ōtani temple in Gifu prefecture and was expected to succeed his father when he grew up. In 1939, at the age of nineteen, he began his studies to become a priest at Ōtani University in Kyoto. The following year, his younger brother, Takashi,

1 (Victoria 2006; Sueki 2004; Nakajima 2017).

2 (Yoshimi 2016; Yoshida 2017) 
joined him in Kyoto. ${ }^{3}$ At the time, Japan was already at war with China, and the entire society was mobilized. After Japan entered the war with the United States in December 1941, university students were also drafted.

Hirose was drafted into the military in February 1942 at the age of twenty-three and was discharged in January 1945. Back in Gifu, Hirose became a priest in his father's temple, where he started a Buddhist youth group, opened a library, and established a community farm on temple land. He died on 20 December 1947, at the age of twenty-eight, presumably from exhaustion. He was survived by his wife, Minamiko, and a son, Shizuka.

In 1970, more than two decades later, Hirose Takashi published his older brother's diary under the title Wakaki kyūdossha no nikki (The diary of a youth who seeks the truth). ${ }^{4}$ The diary consists of two parts: the first part covers the period of time when he was a student at Ötani University from November 1939 to January 1942; the second part includes his years in the army and his life as a priest from February 1942 until August 1946.

\section{Hirose Akira's Vitalism}

Hirose went to Ōtani University to prepare for his future as a priest. Yet he did not feel any joy in what he learned, and his fellow students also seemed to be devoid of spiritual conviction. However, after having studied with Kaneko Daiei (1881-1971) and Soga Ryōjin (1875-1971), Hirose came to realize that all the teachings of Shinran (1173-1263) and Gautama Buddha were directed toward finding one's true self and understanding the preciousness of each and every moment of one's life, which he called vitalism (seimeishugi). ${ }^{5}$ Hirose expressed this as an irrepressible joy:

Now I am being burned by the joy of life. This moment is the moment of joy and fullness of life. This moment coming from the spring of life cannot be replaced by anything else ... Previously my life just followed someone else's teaching. I was wandering among various concepts and looking for religion apart from myself. I must not be a slave of religion and theology. I am alive! I can see now the light of life. (15 September 1941). ${ }^{6}$

During his time at the university, Hirose was critical of the military training performed there. When the military trainers asked students to write about how Shinshū belief contributed to becoming a good subject of the emperor, Hirose responded that the best contribution of Shinshu would be to teach people how to follow one's own inner life (6 December 1940). He was not happy that True Pure Land Buddhism was following a nationalistic trend and that it was even apologetic to the ultranationalists, who accused Shinshū of being anti-kokutai (national polity) $)^{7}$ and irresponsibly escapist. The Shinshū

3 The brothers had the same father but different mothers. Akira never knew his mother, and when he was only three, he became an orphan. He was then raised by his maternal grandparents. When Akira was twenty and a student at Ötani University, his younger brother, Takashi, lived with him for four years until Akira was drafted into the army. Later, Takashi was drafted and sent to Manchuria; a prisoner of war, he was held in Siberia by the Soviet Union. When he was released some years after the war ended, he discovered that his brother had died. Takashi married Akira's widow, Minamiko, and adopted his son, Shizuka. When he read his brother's diary, he was inspired to realize his brother's dream of becoming a Buddhist scholar and professor at Ōtani University. (Hirose 1970, pp. 215-20), and email correspondence with Hirose Shizuka, 29 April 2017.

4 (Hirose 1970).

5 Hirose's vitalism sounds similar to that of Akegarasu Haya 愺烏敏 (1877-1954). In fact, Hirose listened to Akegarasu when the famous preacher visited Ōtani University in July 1941. Unlike Akegarasu's evangelistic vitalism utilized for war propaganda, Hirose's vitalism was personal, and he seems to have been endowed with a more critical mind. I learned a lot about Akegarasu from Fukushima Eiju's article (Fukushima 2006), "Nihonteki Kyōyō to Buddhists during the 1930s" Kikan-Nihon-Shisōshi, vol. 69, (Tokyo: Parican-sha 2006) and Nakajima Takeshi's Shinran to Nihonshugi, (Nakajima 2017, pp. 201-20).

6 Ibid., p. 73. Author's translation. Hereafter, I will indicate the date of Hirose's diary instead of the page number.

7 Kokutai 国体 means "national polity" or "national essence." After the Meiji Restoration in 1868, the government promoted this term to describe Japanese identity, which was associated with rule by an unbroken imperial line and closely linked to State Shinto. The relationship between the emperor (imperial family) and his subjects was compared to that between parents and children. From the late 1930s through World War II, kokutai was a central tenet of the ultranationalism that dominated Japan. 
leadership acknowledged these accusations with these responses. First, Shinshū Honganji-ha (one of the branches of Shinshū) established the Nihon Kyōgaku Kenkyūsho (Center for Research of Japanese Teachings and Doctrines) in May 1941 and eventually created the Senji Kyōgaku Shidō Honbu (Headquarters for Wartime Teachings and Doctrines) in May 1944. ${ }^{8}$ Second, on 5 April 1940, the Shinshū Honganji-ha voluntarily expunged critical passages from Shinran's most important texts, the Kyōgyōshinshō, which includes a passage that reads, "Do not worship the emperor, parents, and kami when you have real faith in the Tathāgata and in Amida Buddha." ${ }^{\prime 9}$ It is important to note that such censorship by the Shinshu authorities was done without coercion by the government. ${ }^{10}$ For Shinshū Ōtani-ha (the branch of Hirose), they had the special meeting Shinshū Kyōgaku Kondankai (Fellowship for Teachings and Doctrines) on 13-15 February in 1941 and decided that the cosmic power of Shinto's Amaterasu and Amida Buddha were identical so that the emperor who embodies Amaterasu was also an embodiment of Amida Buddha's compassion. Thus, Shinshū's faith of total dependence on the Amida Buddha's compassion was equivalent to the total dependence on the emperor's mind; therefore, dying for the emperor at war was also to serve Amida Buddha. ${ }^{11}$

Hirose insisted that True Pure Land Buddhists must stick to Shinran's rejection of worshipping the Shinto kami (Jingi-fuhai) as an expression of the sharp negation of materialistic desire, which had welcomed the kami and shamanistic deities (28 June 1941; 31 July 1941). For Hirose, the True Pure Land Buddhists should not forget their critical view of this world while also avoiding the desire to escape it. They should face up to the reality of the sinful self and hell on earth. He considered that, by digging into one's dark self, one can find true life-vitality, which manifests the grace of the Tathāgata (17 January 1940; 6 May 1941; 16 September 1941).

Even when Hirose was a student, he was worried about the state's suppression of free speech at universities, which he believed would eventually lead to the death of the nation's culture. Hirose came to recognize that Shinran had been able to be critical of himself and of society without being cynical. He believed that True Pure Land Buddhists should return to the original life-vitality of Shinran himself, going beyond an abstract ideology of ultranationalism or Marxism, neither of which were grounded in the ultimate life of the self (2 October 1941).

Hirose was able to point out the hypocrisy behind the totalitarian war mobilization in the name of public service. He wrote:

Nowadays, people are talking about totalitarianism to which individual desire must be subordinated. This is dangerous if it is applied to social policy. Behind this totalitarian policy, there is another kind of selfish desire. The individual will and desire exist before any ideologies (17 September 1940).

The state asked religious leaders to cooperate with the state's moral suasion campaign for the war. Unless you establish your true self, the moral suasion has no meaning. We must return to the original mind seeking the truth (18 September 1940).

Moreover, Hirose criticized the slogans of the army, pointing out the selfish desire for expansionism (26 April 1941). The Konoe Cabinet and the military ratified the National Mobilization Law in 1938. The Greater East Asia Co-Prosperity Sphere was cited as the ideological justification for Japan's aggression over China and Asia.

At the same time, Hirose was engaging in the pursuit of a true self through the study of Buddhism at the university. Years later, he wrote about his hopes for the future in his diary:

\footnotetext{
(Ikeda 1997, p. 162).

Tathāgata is an epithet for the Buddha.

(Shigaraki 1976, pp. 217-48).

(Nakajima 2017, pp. 221-64).
} 
My life's dream would be: First of all, in a quiet countryside, I would like to do a modern translation of Buddhist classics. Nowadays, those classics are confined to the denominational ivory tower. Those classics are abandoned as lifeless antiques. A translation is not just a change from one language to another. This is my work to translate those Buddhist classics to revive their life-vitality now, according to Shinran's attitude of finding the life-vitality of the classics with his sincere pursuit of the true ground of self (6 October 1944).

When war between Japan and the United States broke out following the attack on Pearl Harbor on 7 December 1941, Hirose and his classmates had to put their dreams on hold. The Japanese government decided to mobilize all students, except those in science and technology, by forcing them to graduate early and join the war effort. Hirose graduated on 26 December 1941, with a thesis titled "The Way of Shinran's Negation" (Shinranshōnin no hiteidō). He then joined the 11th Regiment in the city of Toyohashi, Aichi prefecture, on 1 February 1942.

\section{Hirose Akira's Struggle against Militarism}

Contrary to what might be expected, at the beginning of his service, Hirose sincerely accepted life in the army. First of all, he saw how all social and educational backgrounds had become irrelevant. Everyone was considered equal. Hence, he saw it would be an opportunity to know one's true self, as well as to create genuine relationships with all kinds of people. Second, all the knowledge about Buddhism he had learned at the university could be put to the test. Third, his faith could be strengthened and challenged, and the reality of his self-vitality could be observed and tested in life-or-death situations. Finally, Hirose believed that he could contribute to the nation by offering his youthful energy and passion in the service of his country.

Although he was critical of the totalitarian movement during his time as a student, Hirose gradually tried to accept the reality of war as an individual and collective fate (10 April 1943). In other words, Hirose attempted to gain peace and freedom of mind in the midst of war through an understanding of spiritual training, without criticizing the war from an intellectually superior position (14 January 1942).

Hirose was actually inspired by many of the soldiers he served alongside-mostly farmers' sons who helped him with no expectation of thanks. At the same time, he was depressed by the fact that the most selfish, animalistic instinct for survival was revealed in him and others in the army. Hirose often felt the knowledge he learned at the university was useless and that Buddhism was an idealistic, ungrounded faith (16 March 1942; 19 February 1943; 6 March 1943). Swept up in the fervor of serving his country, Hirose often considered the possibility that he would die in battle (19 December 1943).

As early as 1942, Hirose began to wonder why Japan was winning the war since he could detect no real, burning patriotism inside any of the soldiers or people who heteronomously accepted the cold rules and orders from the government under fear of punishment. Only nationalistic slogans existed (30 December 1942).

Hirose read not only Buddhist classics but also many Western philosophers, such as Plato, Schelling, Fichte, Hegel, Nietzsche, and Dostoevsky, since his regiment had day off and he was able to visit bookstores in towns. In terms of patriotism, Hirose praised the ancient Greek cities where each citizen took ownership of the state; in this way, real patriotism emerged autonomously in each citizen (9 December 1942). At any rate, Hirose was influenced most by Shinran, Nietzsche, and Nishida Kitarō (1870-1945). He often compared Shinran's notion of self with Nishida Kitarō's philosophy of personal realization of autonomous will as the supreme good found in Nishida's first book, Zen no kenky $\bar{u}$ (An Inquiry into the Good). ${ }^{12}$

12 Nishida Kitarō, 西田幾多郎uses Kant's definition of heteronomous ethics and autonomous ethics in his book of Zen no kenky ü (Nishida 1990), translated by Masao Abe and Christopher Ives: (New Haven: Yale University Press, 1990). I use these 
Hirose felt that the state was not disclosing the real purpose and meaning of the war to the people; based on both his conscience and his reason, he questioned why the Japanese people must fight the war (9 December 1942; 3 October 1943; 20 October 1943). Hirose also emphasized the significance of Buddhist faith in confronting blind obedience, especially Shinran's concentration on the ultimate foundation of one's self (20 May 1944).

For these reasons, Hirose again became critical of his branch of Shinshū Buddhism. He saw that, instead of taking responsibility for issues of faith and society, the Shinshū leadership was focused on institutional survival, opportunistically allying themselves with the ultranationalists. Hirose insisted that each Shinshū believer must reject denominational pride and become independent-a naked individual bearing the burdens of society (14 September 1943). It is surprising that Hirose was able to contemplate these issues while he was a soldier.

At the time he joined the army, Hirose sincerely believed that the military might be the place for his own spiritual training, but he became disillusioned after the Japanese defeats at the Battle of Midway in June 1942 and at Guadalcanal in February 1943, when many of the problems within the military were revealed. Hirose could not stand the appalling selfishness of senior army leaders who ordered junior soldiers to make sacrifices in the name of public service. Senior leaders enjoyed various privileges, while the frontline soldiers were starving (16 April 1944). Moreover, it was most disturbing for Hirose that many senior leaders enjoyed punishing junior soldiers, relieving their own feelings of anger and frustration, without legitimate lawful reasons or evidence (2 May 1944).

Hirose realized that Japan's defeat was inevitable long before the end of the war. He witnessed the inner and ethical collapse of the authoritarian, heteronomous systems ingrained in the military and in Japanese society, owing to the suppression of the individual's autonomous will and passion. The leaders did not care for or love the frontline soldiers and enjoyed using their high positions for their own private gain in the name of patriotism. They ordered and punished the lower ranks with impunity. Hirose experienced the "transfer of oppression," which Maruyama Masao points out, in the Japanese army and society. ${ }^{13}$ Hirose exclaimed,

How ugly our leaders are! Even the generals of one army section are enjoying themselves under the lights during an air raid (during air raids, turning off all lights was the military order: my quotes). The section leaders are taking 100 pieces of candy for their children while each soldier is given only one every month. All soap is taken by the section leaders to their families and they carried cakes of soap by car, using gasoline whose value was equivalent to human blood at that time. Must such a ridiculous thing exist!? Japan is already defeated whether winning the battle or not. Japan has already collapsed by her own people's ego and selfishness. Therefore, the old Japan is dead now. I hope this is the sign before the new dawn! (8 December 1944).

\section{The Transformation of Hirose's Faith}

During Hirose's three years in the army, he was able to redefine his faith and perspectives on Buddhism. When Japan surrendered on 15 August 1945, Hirose wrote,

The final time has come! Who could predict it four years ago? We are defeated. We can find our true naked selves. Stop the big slogans. We now find that we had nothing other than selfish egotism from the beginning of the war. At this moment, we must look at ourselves honestly, then, with this self-awakening, we are able to rise up from the ashes (22 August 1945).

Back in Gifu, now a True Pure Land Buddhist priest, Hirose wondered how he, a young spiritual leader, could start practicing his beliefs and faith. After the war, the Japanese people suffered from

terminologies as well. See Kant's definition in "Kant's Account of Reason" by Garrath Williams in Stanford Encyclopedia of Philosophy, https:// plato.stanford.edu/entries/kant-reason/.

13 "Theory and Psychology of Ultranationalism," in (Maruyama 1963, pp. 15-20). 
food shortages, widespread poverty, and an overwhelming sense of disillusionment. People tended to seek the Pure Land as an escape from the harsh reality of their lives. Hirose rejected heavenly images and instead emphasized the wholeness of the Pure Land. Rather than escaping to an otherworldly Pure Land, he stressed confronting both our suffering in this world and our innermost self. Ultimately, in the midst of suffering and searching, there is a voice of yearning for liberation, and that is the voice of the Tathāgata. Hirose was straightforward in advocating the necessity to prioritize this inner voice:

Buddhism is not forms and rituals as an objectified image or belief, but the principle or the ground of life itself. It is not our life style or forms but our attitude to life itself. Abandon chanting (nembutsu)! Abandon Shinran! Listen to the voice of the ground of yourself and your existence! (13 February 1945).

This thought process is neither wholly transcendental nor wholly immanent; rather, Hirose's unique immanent transcendentalism is significant. Furthermore, Hirose often felt there was a barrier between the priesthood and the people. In light of this belief, he wanted to be totally independent as a genuine individual of faith. This is how he articulated such yearning:

I want to abandon the temple and priesthood to live naturally. I want to talk to the heart of people as a naked individual freely. I hate my temple background. Ghosts with beautiful Buddha images, which were actually Demons, threatened me and tempted me (31 March 1945).

Acting on his ideas, ${ }^{14}$ Hirose converted a section of his temple into a library, so that the people could have unrestrained access to the classics and other books. He planned to return to Ötani University to fulfill his dream of translating the Buddhist classics. Hirose also organized study groups for young people. In an attempt to alleviate the extreme poverty of the postwar years, Hirose worked with the youth groups to cultivate the land and forests within the temple's property as community cooperatives.

In the last entry in his diary, Hirose left the following note:

To listen to the pledge of the Tathāgata is to be awakened with your real inner voice. If there is some belief, there is still doubt. If there is separation between the Tathāgata and myself, as well as believing and belief, it is not true faith. The Tathāgata is myself and I myself am the Tathāgata (30 August 1946).

It is clear that Hirose had already gone beyond a belief-centered Buddhism. ${ }^{15}$ While actively participating in society and the lives of people, he sought to retain the wholeness of the Pure Land as a criterion for being self-critical, as well as being critical of society without escaping from this world.

\section{Conclusions}

Shinran was critical of the sinfulness of the emperor, politicians, Shinto leaders, and local shamans in regard to the violation of Buddha's eternal law. For Shinran, the Pure Land functioned as a means by which the individual subject becomes independent from this-worldly values and affairs and transcends them. Thus, according to Shinran, Shinshū believers must not worship or immerse themselves in family, tribe, and nation, thereby losing their faith in the Pure Land. ${ }^{16}$

Accordingly, Hirose's understanding of Pure Land faith returned to Shinran's faith, which goes beyond the dichotomy called shinzoku-nitai, the traditional modern Shinshū distinction between ultimate truth (shintai) and conventional truth (zokutai), considered to be the manifestations of the

14 This statement is reminiscent of Dietrich Bonhoeffer's notion of religionless faith and action against cheap grace in (Bonhoeffer 1959, pp. 41-102). Dietrich Bonhoeffer (1906-1945), a German Lutheran pastor and anti-Nazi dissident, was executed in April 1945 at the Flossenbürg concentration camp.

15 Sueki Fumihiko mentioned that modern Japanese Buddhism was influenced by the Protestant notion of belief-centered religiosity based on a personal and private faith (presentation at the conference Tracing Japanese Buddhism, UC Berkeley, 25 September 2009).

16 (Shigaraki 1976). 
Tathāgata and Amida Buddha. Hirose also went beyond Shinshū's mind-body dualism in which the mind belongs to the Pure Land in the inner private realm and the body belongs to the conventional truth in the outer public realm.

It would be significant that Hirose's non-dualistic, action-oriented faith goes beyond the traditional Shinshū dichotomy of ultimate truth and conventional truth. ${ }^{17}$ Japanese Pure Land Buddhists, since it focused on the inner private realm of faith as well as a total dependency on the grace of the "Wholly Other," so that they were less critical toward the state. Except for the resistance of a few individuals such as Takenaka Shōgen, their main religious institutions accepted the totalitarian regimes. ${ }^{18}$

Total dependency on the grace of the "Wholly Other" while waiting for the Pure Land works well in the private and individual realm. However, we cannot live without relationship with others, society, the nation, and the world. Thus, Pure Land Buddhists must expand their inner personal faith into ethical decision-making, guided by Buddha's Law, using their own free will to decide what to accept or reject in this world. This deliberate decision-making contributes toward a Buddhist social ethics. Pure Land Buddhists neglected free will and critical reason because of their emphasis on sinful human nature, which renders us helpless to save ourselves. This may be true on the inner or individual level, but we need to approach decision-making in the public realm with a critical analysis of the social structure. Hirose Akira was oriented in this direction.

If he had lived longer, Hirose undoubtedly would have developed a True Pure Land social ethics in postwar Japan, contributing to the reform of Buddhism and society. There were young, conscientious Buddhist soldiers like Hirose struggling to reconcile their Buddhist principles with violence caused by the war. Even so, once the war started, it was difficult to resist the war as an individual, either in speech and or in action. Hirose's story nevertheless raises the critical question of whether the collective actions of Japanese Buddhism could have resisted the war. Ultimately, we cannot know the answer to this question, yet the story of this young, brilliant, and prophetic Buddhist soldier reminds us that should the opportunity for a collective, faith-based resistance to the violence of war arise again in the future, we should have the wisdom to carry out Hirose Akira's unfulfilled dream.

Conflicts of Interest: The authors declare no conflict of interest.

\section{References}

Bonhoeffer, Dietrich. 1959. The Cost of Discipleship. New York: SCM Press.

Daitō, Hitoshi. 2008. War Is Sinful, Anti-War Priest, Takenaka Shōgen. Nagoya: Fūbaisha.

Fukushima, Eiju. 2006. Nihonteki Kyōyō to Buddhists during the 1930s. Kikan-Nihon-Shisōshi 69.

Hirose, Akira. 1970. Wakaki kyūdōsha no nikki 若き求道者の日記 (The Diary of a Youth Who Seeks Truth). Tokyo: Yayoishobō.

Ikeda, Gyōshin. 1997. Shinshū kyōdan no shisō to kōdō 真宗教団の思想と行動 (The Thought and Actions of the Shinshu Organizations). Kyoto: Hōzōkan.

Maruyama, Masao. 1963. Thought and Behavior in Modern Japanese Politics. New York: Oxford University Press.

Nakajima, Takeshi. 2017. Shinran to Nihonshugi. Tokyo: Shinchō Sensho.

Shigaraki, Takamaro. 1976. Senjika no Nihon bukkyō: Shinshū no seiten sakujo mondai 戦時下の日本仏教: 聖典削除問

題 (Japanese Buddhism during Wartime: The Issue of Deleted Passages in the Scriptures). Tokyo: Kokusho kankōkai. Sueki, Fumihiko. 2004. Kindai Nihon to Bukkyo. Tokyo: Trans-review.

Victoria, Daizen Brian. 2006. Zen at War, 2nd ed. London: Rowman \& Littlefield.

17 (Bonhoeffer 1959, pp. 41-99). It reminds that Bonhoeffer's religionless faith and action beyond the Lutheran tradition of Two Kingdoms. German Lutherans had similar difficulties in resisting the totalitarian regimes during 1930-1945.

18 Takenaka Shōgen 竹中彰元 was a True Pure Land Buddhist priest of Myōsen-ji, who criticized the Fifteen Year War as sinful and foolish wastes in 1937. Takenaka was arrested and his status of priesthood was made lowest by Ōtani-ha. See (Daitō 2008). 
Yoshimi, Yoshiaki. 2016. Kusanone no Fascism (Grassroots Fascism). Translated by Ethan Mark. New York: Columbia University Press.

Yoshida, Yutaka. 2017. Nihongunheishi. Tokyo: Chukoshinsho.

Nishida, Kitarō. 1990. Zen no kenkyū (An Inquiry into the Good). Translated by Masao Abe and Christopher Ives. New Haven: Yale University Press. 